Ewelina Wilińska', Karina Oniszh ${ }^{2}$, Ewa Augustynowicz-Kopeć ${ }^{3}$, Anna Zabost ${ }^{3}$, Anna Fijałkowska ${ }^{4}$, Marcin Kurzyna ${ }^{5}$, Maria Wieteska ${ }^{5}$, Adam Torbicki ${ }^{5}$, Jan Kuś ${ }^{6}$, Monika Szturmowicz ${ }^{6}$

'National Institute of Tuberculosis and Lung Diseases, Warsaw, resident

${ }^{2}$ Department of Radiology and Diagnostic Imaging, National Institute of Tuberculosis and Lung Diseases, Warsaw

Head: I. Bestry, MD

${ }^{3}$ Department of Microbiology, Institute of Tuberculosis and Lung Diseases, Warsaw

Head: Prof. E. Augustynowicz-Kopeć, MD, PhD

${ }^{4}$ Department of Cardiology, National Research Institute for Mother and Child

Head: Prof. A. Fijałkowska, MD, PhD

${ }^{5}$ Department of Pulmonary Circulation and Thromboembolic Diseases, European Health Centre Otwock

Head: Prof. A. Torbicki, MD, PhD

${ }^{6}$ First Department of Lung Diseases, National Institute of Tuberculosis and Lung Diseases, Warsaw

Head: Prof. J. Kuś, MD, PhD

\title{
Non-tuberculous mycobacterial lung disease (NTMLD) in patients with chronic thromboembolic pulmonary hypertension and idiopathic pulmonary arterial hypertension
}

\author{
Mikobakterioza płuc u chorych na nadciśnienie płucne zakrzepowo-zatorowe \\ i idiopatyczne tętnicze nadciśnienie płucne
}

The authors declare no financial disclosure

\begin{abstract}
Introduction: Non-tuberculous mycobacterial lung diseases (NTMLD) occur rarely and are diagnosed mainly in patients belonging to risk groups. Pulmonary hypertension (PH) has not been recognised as a risk factor for NTMLD yet.

The aim of the study was to analyse the clinical course and predisposing factors of NTMLD recognised in our centre between 2002 and 2012 in patients with chronic thromboembolic pulmonary hypertension (CTEPH) and idiopathic pulmonary arterial hypertension (IPAH).

Material and methods: Thirteen patients (10 - CTEPH, 3 - IPAH) entered the study. PH was recognised during right heart catheterisation. Median value of mean pulmonary artery pressure (mPAP) was $49 \mathrm{~mm} \mathrm{Hg}(39-65 \mathrm{~mm} \mathrm{Hg})$. NTMLD was diagnosed according to ATS guidelines (2007).

Results: $M$. kansasii was the most frequent pathogen. Most patients complained of the exaggeration of dyspnoea and productive cough. Computed tomography of the chest with angiography revealed infiltrations with cavitation in seven patients and cavities surrounded by micronodules in six patients. In all CTEPH patients, NTMLD developed in the hypoperfused lung areas. No parenchymal abnormalities preceded the development of NTMLD. After diagnosis all of the patients received antituberculous treatment; in 12/13 improvement was achieved. By the end of March 2014 seven patients died due to right heart insufficiency, no deaths due to NTMLD were noted.

Conclusions: NTMLD should be suspected in patients with CTEPH or IPAH, presenting with productive cough and a new pulmonary infiltrate with cavitation. In patients with CTEPH, special attention should be paid to a new cavitary lesions without accompanying thrombus in the artery supplying the area. High mPAP (CTEPH/IPAH) and hypoperfusion (CTEPH) are predisposing to NTMLD.
\end{abstract}

Key words: non-tuberculous mycobacterial lung disease, chronic thromboembolic pulmonary hypertension, idiopathic pulmonary arterial hypertension, lung hypoperfusion

Pneumonol. Alergol. Pol. 2014; 82: 495-502

Address for correpondence: Prof. Monika Szturmowicz, First Department of Lung Diseases, National Institute of Tuberculosis and Lung Diseases, ul. Płocka 26 01-138 Warszawa, tel.: +48 2243121 00, fax: +48 22431 24 52, e-mail: monika.szturmowicz@gmail.com

DOI: 10.5603/PiAP.2014.0066

Praca wpłynęła do Redakcji: 22.04.2014 r.

Copyright ( 2014 PTChP

ISSN 0867-7077 


\begin{abstract}
Streszczenie
Wstęp: Mikobakteriozy są chorobami rzadkimi, rozpoznawanymi głównie u osób z grup ryzyka. Wśród płucnych czynników ryzyka nie wymieniono dotychczas nadciśnienia płucnego.

Celem pracy była analiza obrazu klinicznego i przebiegu mikobakteriozy płuc, którą rozpoznano w ośrodku autorów pracy w latach 2002-2012 u chorych na nadciśnienie płucne zakrzepowo-zatorowe (CTEPH) i idiopatyczne (IPAH), oraz próba określenia czynników sprzyjających zachorowaniu.

Materiał i metody: Badaną grupę stanowiło 13 chorych — 10 z CTEPH i 3 z IPAH. Nadciśnienie płucne potwierdzono metodą inwazyjną. Mediana średniego ciśnienia w tętnicy płucnej w okresie rozpoznania mikobakteriozy wynosiła $49 \mathrm{~mm} \mathrm{Hg} \mathrm{(39-65} \mathrm{mm} \mathrm{Hg).}$ Mikobakteriozę płuc rozpoznano zgodnie z kryteriami Amerykańskiego Towarzystwa Chorób Płuc z 2007 roku.

Wyniki: Czynnikiem etiologicznym był u większości chorych gatunek M. kansasii. Najczęstszymi objawami mikobakteriozy płuc były nasilenie duszności i produktywny kaszel. W tomografii komputerowej klatki piersiowej z opcją naczyniową w 7 przypadkach stwierdzono zagęszczenia miąższowe z rozpadem, w 6 - jamy otoczone drobnymi guzkami. U wszystkich chorych na CTEPH zmiany związane z mikobakteriozą pojawiły się na obszarach o upośledzonej perfuzji, ale bez widocznych zmian pozawałowych. Wszyscy chorzy otrzymali leczenie przeciwprątkowe, uzyskano poprawę w 12/13 przypadków. Do kwietnia 2014 roku 7 chorych zmarło z powodu ciężkiej prawokomorowej niewydolności serca, nie obserwowano zgonów w przebiegu mikobakteriozy.

Wnioski: Nowe płucne zmiany miąższowe z rozpadem u chorych na CTEPH i na IPAH z towarzyszącym produktywnym kaszlem powinny skłonić do diagnostyki w kierunku mikobakteriozy płuc. W CTEPH niepokój budzą szczególnie ogniska rozpadu, którym nie towarzyszą nowe skrzepliny w naczyniach doprowadzających. Czynnikami sprzyjającymi rozwojowi mikobakteriozy płuc są: wysokie nadciśnienie płucne (CTEPH i IPAH) oraz obniżona perfuzja (CTEPH).
\end{abstract}

Słowa kluczowe: mikobakterioza płuc, nadciśnienie płucne zakrzepowo-zatorowe, idiopatyczne tętnicze nadciśnienie płucne, hipoperfuzja płuc

Pneumonol. Alergol. Pol. 2014; 82: 495-502

\section{Introduction}

Non-tuberculous mycobacterial lung diseases (NTMLD) are caused by non-tuberculous mycobacteria, also known as atypical mycobacteria. They are saprophytic bacteria, which are widely spread in the environment, among others in soil and in water $[1,2]$. Infection with atypic mycobacteria happens due to inhalation of pathogens included in water aerosols, soil derived dust, or through injured skin. Atypical mycobacteria cause mainly lung disease; they rarely cause lymphadenitis, dermatitis, soft tissue infection, or disseminated disease [1,2].

NTMLD occur rarely. According to data published in 2007 by the ATS, the estimated incidence rate of NTMLD in developed countries varied from 1.0 to 1.8 cases per 100,000 [1]. Research conducted in several states in the USA between 2004-2006 showed a higher incidence rate -5.4 per 100,000 [3]. Similar observations were made in the state of Oregon in 2005 and 2006, where the incidence rate of NTMLD was estimated at 5.6 cases per 100,000 [4]. NTMLD occur more frequently in people living in warm and humid climatic zones, due to more intensive exposure to the environmental mycobacteria. In northern Australia, where the climate is hot and tropical, and where NTMLD is registered, in the years 1989-1997 the incidence rate amounted to 3.9 per 100,000 people [5].
NTMLD is also more frequent in people whose profession is connected with the mining and smelting industry [1, 6, 7], and in smokers. Tobacco smoke and exposure to inorganic dusts damage the mucous membrane of the respiratory system, causing impairment of local mechanisms of defence.

According to the literature, NTMLD is most often caused by M. avium complex (MAC) [8, 9], then by $M$. kansasii, $M$. xenopi, M. malmoense, and rapidly growing mycobacteria (RGM). In Poland, according to several available studies and the data of the National Institute of Hygiene, NTMLD is most frequently caused by $M$. kansasii [10-12].

The disease that is caused by non-tuberculous mycobacteria mainly affects people from risk groups. The risk groups of NTMLD include the following:

- individuals with past or current lung disease (COPD, bronchiectasis, cystic fibrosis, past pulmonary tuberculosis, cystic disease of the lungs, silicosis, allergic broncho-pulmonary aspergillosis, pulmonary alveolar proteinosis) $[1,2,8]$;

- individuals with deformation of the chest such as kyphoscoliosis and pectus excavatum [13];

- patients exposed to the aspiration of gastric contents in the course of gastroesophageal reflux, achalasia of the oesophagus [6, 14]; 
- patients with generalised disorders of immunity (neoplastic diseases, HIV infection, immunosuppressive treatment) $[1,6]$.

NTMLD has also been found in persons with rheumatologic diseases or inflammatory bowel diseases, treated with $\mathrm{TNF} \alpha$ antagonists such as monoclonal antibodies - infliximab and adalimumab, and $\mathrm{TNF} \alpha$ receptor antagonist - etanercept $[6,15]$. The risk of occurrence of NTMLD is significantly higher in individuals with genetic disorders concerning IFN- $\gamma$ or IL-12 receptors [6, $8,16]$. Important sources of infection are factors connected with medical care [1, 17], in particular hospital water intakes, water used for ice production or for dialysis, and long-lasting central catheterisation. There have been reported cases of hospital infections after various operations, particularly those concerning plastic surgery, cardiosurgery, or during bronchoscopy.

The recently reported increase in the incidence of NTMLD is presumably related to improved laboratory diagnostics and a growing number of people from risk groups $[18,19]$. To date, the relation between $\mathrm{PH}$ and NTMLD has not been described. Our group published the only study concerning this issue [20]. As subsequent cases of NTMLD in patients with PH in the following years have been diagnosed in our clinic, we decided to pay attention to this clinical problem.

The objective of the study was to analyse the clinical image and the course of NTMLD in patients with CTEPH and IPAH, and to define potential risk factors of NTMLD in patients with pulmonary hypertension.

\section{Material and methods}

The study group included 13 patients (10 with CTEPH, 3 with IPAH), who were diagnosed with NTMLD between 2002 and 2012. Pulmonary hypertension was confirmed using right heart catheterisation in all patients; however, the results for only 11 persons were available. One female patient with CTEPH underwent cardiac catheterisation at another centre and at present we have $\mathrm{n}$ ot had access to the results of the examination. In another female patient after urgent, ineffective thromboendarterectomy of the pulmonary artery, post-operative cardiac catheterisation was not performed due to the poor health condition of the patient and no prospect for further causal treatment.

Thromboembolic pulmonary hypertension was diagnosed based on chest spiral CT scan with angiography or arteriography of the pulmonary artery, which showed typical filling defects of the pulmonary artery. IPAH was diagnosed after exclusion of other causes of PH. NTMLD was diagnosed in accordance with the criteria of the American Thoracic Society (ATS) of 2007 [1] in the patients with new clinical symptoms of lung disease, new radiological signs that suggested NTMLD, and if microbiological criteria were met (positive sputum culture results from at least two separate samples or positive culture results from at least one bronchial washing sample).

\section{Results}

Clinical data of the patients are presented in Table 1 . The study group included eight men and five women, median age was 34 years (range from 22 to 76 years). Most of the patients had low body mass index, median BMI was $23 \mathrm{~kg} / \mathrm{m}^{2}(17.6-27.7)$.

The most frequent sign of NTMLD was exaggeration of dyspnoea, which was found in 11 patients. Eight patients complained of cough (productive, with the expectoration of purulent sputum, in six; dry in two). Haemoptysis, elevated body temperature, pleuritic chest pain, and strength reduction were found sporadically.

Chest angio CT scans performed prior to the diagnosis of NTMLD and those that were performed at the time of NTMLD were analysed. In all patients with CTEPH, the scans performed prior to the diagnosis revealed mosaic perfusion including more than $50 \%$ of the lung fields. In six out of ten patients angio CT scan showed postinflammatory and postinfarction scars, which in five cases were located in areas other than later lesions in the course of NTMLD, and in one patient - in the same area.

In all patients with IPAH, parenchymal abnormalities were found, in two cases they were ground-glass opacities, and in one case they were nodules of the central part of the pulmonary lobule located in the whole lungs. Furthermore, in all patients, chest angio CT showed the features of significant pulmonary hypertension; median width of pulmonary artery trunk was $38 \mathrm{~mm}$ (the normal size is up to $29 \mathrm{~mm}$ ). In the group of CTEPH patients, in five cases, proximally located thrombi were found, whereas in five patients thrombi were distal (segmental vessels). Chest angio CT scans performed when NTMLD was diagnosed revealed the following:

- in seven patients - infiltrations with cavitation and with the presence of small satellite nodules; - in six persons - cavities surrounded by micronodules (Fig. 1). 
Table 1. Age, BMI, clinical and radiological symptoms, and the number of positive sputum (S) and bronchial washing (BW) examinations targeted at mycobacteria in individual patients (Pt) with diagnosed mycobacteriosis

\begin{tabular}{|c|c|c|c|c|c|c|c|c|}
\hline \multirow[t]{2}{*}{ Pt } & \multirow[t]{2}{*}{ Diagnosis } & \multirow[t]{2}{*}{$\begin{array}{c}\text { Age } \\
\text { (years) }\end{array}$} & \multirow[t]{2}{*}{$\begin{array}{c}\text { BMI } \\
{\left[\mathrm{kg} / \mathrm{m}^{2}\right]}\end{array}$} & \multirow[t]{2}{*}{ Clinical symptoms } & \multirow[t]{2}{*}{ Radiological symptoms } & \multicolumn{3}{|c|}{$\begin{array}{l}\text { Positive examination targeted } \\
\text { at mycobacteria }\end{array}$} \\
\hline & & & & & & $\begin{array}{l}\text { Direct } \\
\text { examination } \\
\text { S/BW }\end{array}$ & $\begin{array}{l}\text { Culture } \\
\text { S }\end{array}$ & $\begin{array}{l}\text { Culture } \\
\text { BW }\end{array}$ \\
\hline 1 & CTEPH & 33 & 23.4 & Intensified dyspnoea & Cavity, satellite nodules & 2 & 2 & 1 \\
\hline 2 & СТЕРH & 47 & 17.6 & $\begin{array}{l}\text { Cough, strength reduction, } \\
\text { intensified dyspnoea }\end{array}$ & Cavity, satellite nodules & - & 2 & 1 \\
\hline 3 & CTEPH & 67 & 24.1 & Intensified dyspnoea & $\begin{array}{l}\text { Infiltrations with cavitation, } \\
\text { satellite nodules }\end{array}$ & - & 1 & 1 \\
\hline 4 & CTEPH & 49 & 27.7 & Intensified dyspnoea & $\begin{array}{l}\text { Infiltrations with cavitation, } \\
\text { satellite nodules }\end{array}$ & - & 1 & 1 \\
\hline 5 & CTEPH & 59 & 23.4 & $\begin{array}{l}\text { Cough, haemoptysis, inten- } \\
\text { sified dyspnoea }\end{array}$ & $\begin{array}{l}\text { Thick-walled cavities, satel- } \\
\text { lite nodules }\end{array}$ & 1 & 3 & 1 \\
\hline 6 & CTEPH & 25 & 22.9 & Intensified dyspnoea & Infiltrations with cavitation & 1 & 1 & 1 \\
\hline 7 & СТЕРH & 25 & 18.4 & $\begin{array}{l}\text { Cough, strength reduction, } \\
\text { intensified dyspnoea }\end{array}$ & $\begin{array}{l}\text { Infiltrations with cavitation, } \\
\text { satellite nodules }\end{array}$ & 2 & 2 & 1 \\
\hline 8 & CTEPH & 33 & 19.6 & $\begin{array}{l}\text { Haemoptysis, dyspnoea, } \\
\text { cough }\end{array}$ & Infiltrations with cavitation & 1 & 2 & 1 \\
\hline 9 & CTEPH & 34 & 21.1 & $\begin{array}{l}\text { Cough, intensified dyspno- } \\
\text { ea, subfebrile body tempe- } \\
\text { rature }\end{array}$ & $\begin{array}{l}\text { Thick-walled cavities, satel- } \\
\text { lite nodules }\end{array}$ & 4 & 4 & - \\
\hline 10 & CTEPH & 54 & 31.3 & Cough & Infiltrations with cavitation & - & 1 & 1 \\
\hline 11 & IPAH & 76 & 23 & $\begin{array}{l}\text { Fever, pain in the chest, } \\
\text { intensified dyspnoea }\end{array}$ & Cavity, satellite nodules & 2 & 3 & - \\
\hline 12 & IPAH & 22 & 21.4 & Cough, dyspnoea & Cavity, satellite nodules & - & - & 1 \\
\hline 13 & IPAH & 30 & 23.2 & Cough & $\begin{array}{l}\text { Infiltrations with cavitation, } \\
\text { satellite nodules }\end{array}$ & - & - & 1 \\
\hline
\end{tabular}
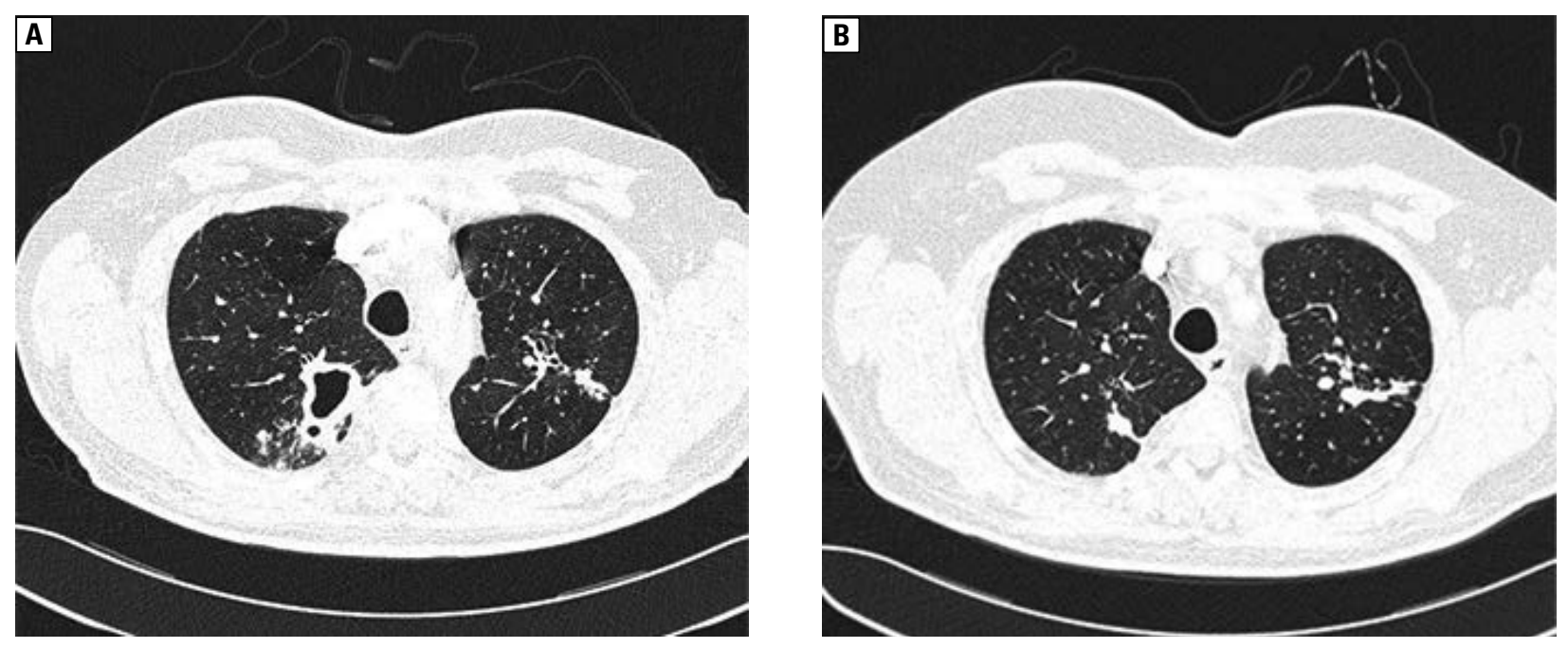

Figure 1. High-resolution CT (HRCT) in the patient with CTEPH and mycobacterial lung disease, performed before and after treatment of mycobacteriosis. A - HRCT performed before treatment of mycobacterial lung disease: thick-walled cavity with satellite nodules localised in the right upper lobe, with infiltration localised in left upper lobe; B - HRCT taken after treatment: marked regression of lung infiltrations, post-inflammatory scars seen in both regions 
In all patients with CTEPH, lesions related to NTMLD occurred in hypoperfused lung areas (Figure 2). In eight patients with CTEPH, there were no reports of new thrombi in pulmonary

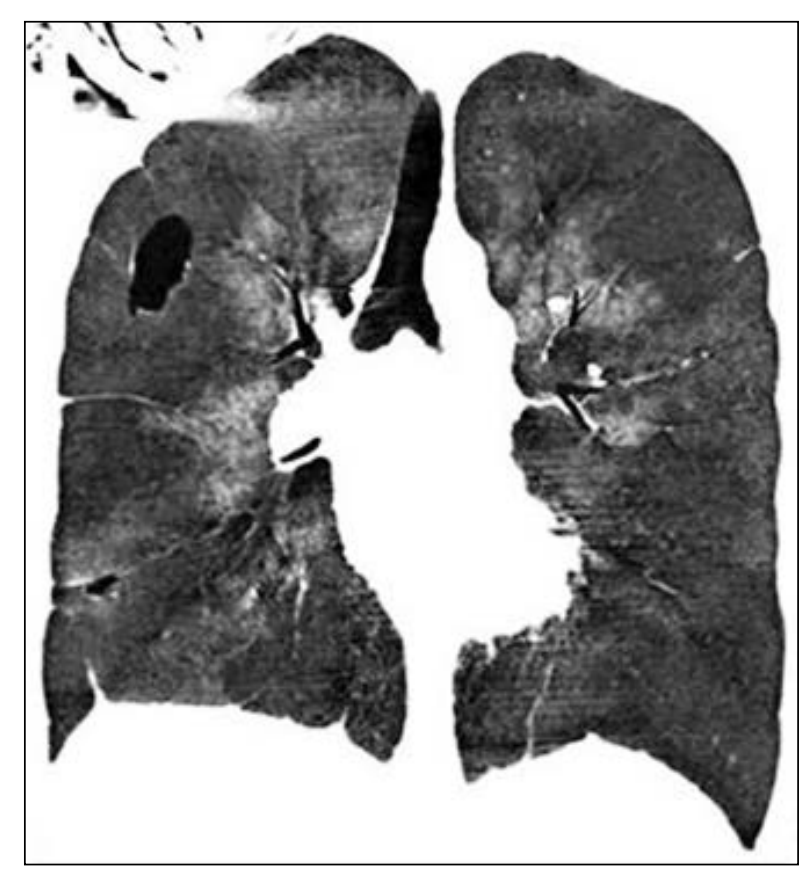

Figure 2. Chest angio CT - frontal view (reconstruction) in a patient with CTEPH and mycobacterial lung disease. The cavity seen in the right lung is localised in the hypoperfused area arteries at the time when NTMLD occurred, and in two - new thrombi of different location than lesions in the course of NTMLD appeared.

In 11 patients, NTMLD was caused by M. kansasii, and in one person - by M. xenopi. In one patient, M. kansasii was originally cultured then, one year later, a new infection with $M$. xenopi was found. In two patients, diagnosis was microbiologically confirmed by a single sample of bronchial washings, in the subsequent two patients - by at least three sputum specimens, and in the remaining patients - by at least two cultures from sputum and from bronchial washings. Mycobacteria in the direct preparation were found in seven patients (Tab. 1).

In the majority of patients, at the time of NTMLD, high pulmonary hypertension was present. The results of echocardiography and right heart catheterisation are presented in Table 2 . The median value of the tricuspid valve pressure gradient (TVPG) in echocardiography was 80 $\mathrm{mm} \mathrm{Hg} \mathrm{(38-103} \mathrm{mm} \mathrm{Hg}$ ), whereas the median of mean pulmonary arterial pressure (mPAP) was $49 \mathrm{~mm} \mathrm{Hg}(39-65 \mathrm{~mm} \mathrm{Hg})$. Those patients were distinguished by low values of cardiac index (CI) [median CI: $2.18 \mathrm{l} / \mathrm{min} / \mathrm{m}^{2}\left(1.68-3.05 \mathrm{l} / \mathrm{min} / \mathrm{m}^{2}\right)$ ], cardiac output (CO) [median CO: 4.14 l/min (3.07$6.03 \mathrm{l} / \mathrm{min}$ )], and mixed venous blood saturation $\left(\mathrm{SatO}_{2} \mathrm{mv}\right)$ [median $\left.\mathrm{SatO}_{2} \mathrm{mv}: 54 \%(38-73 \%)\right]$.

Table 2. Selected echocardiographic and haemodynamic parameters in individual patients (Pt) with mycobacteriosis (1-10: CTEPH patients, 11-13: IPAH patients)

\begin{tabular}{|c|c|c|c|c|c|c|c|c|c|c|c|}
\hline $\mathbf{P t}$ & $\begin{array}{c}\text { TVPG } \\
{[\mathrm{mm} \mathrm{Hg}]}\end{array}$ & AcT [ms] & $\begin{array}{c}\mathrm{rPK} \\
{[\mathrm{mm}]}\end{array}$ & $\begin{array}{c}\text { RAP } \\
{[\mathrm{mm} \mathrm{Hg}]}\end{array}$ & $\begin{array}{c}\text { PAPm } \\
{[\mathrm{mm} \mathrm{Hg}]}\end{array}$ & $\begin{array}{c}\text { PCWP } \\
{[\mathrm{mm} \mathrm{Hg}]}\end{array}$ & $\mathrm{CO}\left[\mathrm{l} / \mathrm{m}^{2}\right]$ & $\begin{array}{c}\mathrm{SatO}_{2} \mathrm{mv} \\
(\%)\end{array}$ & $\begin{array}{c}\mathrm{Cl}[\mathrm{l} / \mathrm{min} / \\
\left.\mathrm{m}^{2}\right]\end{array}$ & $\begin{array}{c}\text { PVR } \\
\text { [Wood's } \\
\text { units] }\end{array}$ & $\begin{array}{c}\text { Sat0 }_{2} \\
\text { art. (\%) }\end{array}$ \\
\hline 1 & 86 & 67 & 34 & 13 & 46 & 4 & 4.23 & 49 & 2.25 & 9.93 & 90 \\
\hline 2 & 46 & 70 & 33 & 9 & 39 & 10 & 4.15 & 65 & 2.17 & 6.99 & 94 \\
\hline 3 & 90 & 53 & 49 & 13 & 58 & 8 & 4.14 & 54 & 2 & 12.08 & 85 \\
\hline 4 & 82 & 53 & 33 & 21 & 65 & 8 & 4 & 49 & 2.21 & 14.25 & 93 \\
\hline 5 & 75 & 40 & 43 & 9 & 49 & 8 & 4 & 61 & 2.18 & 10.25 & 85 \\
\hline 6 & 77 & 50 & 47 & 7 & 44 & 6 & 5.3 & 73 & 3.02 & 7.17 & 94 \\
\hline 7 & 103 & 60 & 34 & 14 & 65 & 8 & 4.04 & 47 & 2.09 & 14.11 & 96 \\
\hline 8 & 65 & 78 & 30 & 6 & 48 & 4 & 4.95 & 64 & 2.53 & 8.89 & 98 \\
\hline 9 & 80 & 53 & 44 & ND & ND & ND & ND & ND & ND & ND & ND \\
\hline 10 & 38 & 80 & 36 & ND & ND & ND & ND & ND & ND & ND & ND \\
\hline 11 & 83 & 73 & 30 & 9 & 54 & 11 & 3.43 & 43 & 2.13 & 12.54 & 89 \\
\hline 12 & 91 & 53 & 50 & 6 & 54 & 6 & 3.07 & 38 & 1.68 & 15.64 & 93 \\
\hline 13 & 76 & 63 & 36 & 21 & 49 & 9 & 6.03 & 68 & 3.05 & 6.14 & 94 \\
\hline
\end{tabular}

TVPG — tricuspid valve peak gradient; Act — pulmonary artery acceleration time; rPK — right ventricular diastolic diameter; RAP — right atrial pressure; PAPm — mean pulmonary artery pressure; PCWP — pulmonary artery wedge pressure; $\mathrm{CO}$ - cardiac output; sat $\mathrm{O}_{2}$ mv — mixed venous blood oxygen saturation; $\mathrm{Cl}$ - cardiac index; PVR — pulmonary vascular resistance; $\mathrm{SatO}_{2}$ art. — arterial blood oxygen saturation; $\mathrm{ND}$ - no data 
Table 3. Treatment schedules applied in patients with mycobacteriosis and pulmonary hypertension

\begin{tabular}{lc}
\hline $\begin{array}{l}\text { Number } \\
\text { of patients }\end{array}$ & Treatment \\
\hline 7 & $\mathrm{RMP}, \mathrm{NHH}, \mathrm{EMB}$ \\
2 & $\mathrm{RMP}, \mathrm{INH}$, clarithromycin \\
1 & $\mathrm{RMP}, \mathrm{NNH}$, ofloxacin \\
1 & $\mathrm{RMP}, \mathrm{INH}, \mathrm{EMB}$, clarithromycin \\
1 & $\mathrm{RMP}, \mathrm{EMB}$, ofloxacin, amikacin \\
1 & $\mathrm{INH}, \mathrm{EMB}$, ofloxacin, clarithromycin \\
\hline RMP - rifampicin; INH - isoniazid; EMB - ethambutol
\end{tabular}

In $11 / 13$ patients, advanced WHO class was found (nine persons - III, two persons - IV), the remaining two persons were in II class. Median value of $\mathrm{N}$-terminal fraction of brain natriuretic peptide (NTproBNP) was $2195 \mathrm{pg} / \mathrm{ml}$ (723-9663 $\mathrm{pg} / \mathrm{ml}$ ), which confirmed additionally the presence of advanced right heart insufficiency.

In the study group, we found no increased frequency of diseases of the respiratory system that are known risk factors of NTMLD. Only in one female patient with IPAH, past pulmonary tuberculosis was found (location of post-tuberculous lesions did not correspond to the location of lesions in the course of NTMLD), and in one patient with CTEPH, hiatus hernia was diagnosed. All patients were qualified for treatment of NTMLD. Most of the patients were treated with rifampicin (RMP), isoniazid (INH) and ethambutol (EMB) (Tab. 3). Median treatment time was 18 months (3-26 months). Positive results of treatment were achieved in 12 patients: regression of clinical symptoms, regression of radiological lesions (Figure 1), and sterilisation of sputum specimens. In one female patient, no radiological improvement was observed. Seven patients $(6-$ CTEPH and 1 - IPAH) died before April 2014. In all cases, the cause of death was severe right heart insufficiency. In no case was NTMLD the cause of death. Median time from the diagnosis of NTMLD to death was 25 months (8-84 months).

\section{Discussion}

Non-tuberculous mycobacterial lung disease occurs mainly in individuals from risk groups. According to the literature, the incidence of NTMLD in patients with cystic fibrosis amounts to approximately $3 \%$ [21], in patients with bronchiectasis $2-3 \%$ [22, 23], and in persons with past pulmonary tuberculosis approximately $2 \%$ [24].
Higher incidence was observed in individuals treated with anti-TNF $\alpha$ preparations [25] and in HIV infected patients, in whom the risk of infection increases together with lowering of lymphocyte count CD4+ [26].

The present observational study, conducted at the pulmonary hypertension treatment centre, showed that during ten years NTMLD was diagnosed in 11 patients with thromboembolic pulmonary hypertension and in three patients with idiopathic pulmonary arterial hypertension. In a $\mathrm{PhD}$ thesis of $\mathrm{E}$. Wilińska, the prevalence of NTMLD in patients with CTEPH and IPAH in the years 2002-2008 was estimated at 3.5\% [27].

These data show that the incidence of NTMLD in patients with pulmonary hypertension (CTEPH and IPAH) is similar to the incidence of NTMLD in patients with other chronic pulmonary diseases that are considered to be risk groups.

In 12 cases from the study group, the pathogen was M. kansasii. This mycobacterium species is the most frequent cause of NTMLD in Poland, which is confirmed in the literature $[10,11]$ and by the National Institute of Hygiene [12]. In studies conducted in other countries, the most frequent cause of NTMLD was MAC, whereas $M$. kansasii was the second (in terms of frequency) cause of NTMLD in some regions of the USA, Great Britain, and Japan [1].

In the present study, in patients with NTMLD and PH, the most frequent signs of NTMLD were exaggeration of dyspnoea and productive cough. Exercise dyspnoea and restricted exercise tolerance are reported by the majority of patients with advanced pulmonary hypertension; these symptoms depend in most cases on the degree of heart insufficiency, and in CTEPH patients, they may be related to progression or the appearance of new thrombi in the pulmonary vessels. In the opinion of the authors, diagnostics targeted at respiratory system infection should be implemented in every case of unclear cause of worsened exercise tolerance in patients with $\mathrm{PH}$, particularly in the individuals with productive cough. It is emphasised in the literature that the symptoms of NTMLD are untypical, and they usually include chronic or recurrent cough with sputum expectoration, rarely strength reduction, subfebrile body temperature, haemoptysis, pain in the chest, weight loss, and dyspnoea [1, 2, 28, 29].

In the radiological image of patients with pulmonary hypertension and NTMLD, infiltrations with cavitation or cavities with satellite nodules were found. Such a radiological image 
is typical of the disease caused by M. kansasii and $M$. xenopi [1].

The appearance of new infiltrations with cavitation in CTEPH patients may arouse a suspicion of the recurrence of pulmonary embolism. A significant diagnostic element in such cases is the presence or lack of new embolic lesions in the vessels supplying blood to the area of the lesion. The lack of new vascular lesions in CTEPH patients in whom new infiltrations and cavitation are found in chest angioCT scan, should lead to diagnostics targeted at the respiratory system infection. In the study group, in eight cases, new infiltrations with cavitation that were found on chest angio CT scan, were not accompanied by vascular lesions, and in two cases new thrombi were found, but they were located outside the area with infiltrations.

Among the factors that could influence an increased risk of NTMLD in patients with PH, structural lesions that could be the base for colonisation with non-tuberculous mycobacteria, such as scars, foci of fibrosis, or postinfarction cavities in CTEPH patients, were taken into consideration. It was shown that only in one CTEPH patient, NTMLD developed in the area where postinfarction scar was seen previously. In another five CTEPH patients, on the chest angio CT scan that preceded NTMLD, postinflammatory and postinfarction scars were found, but they were located in other regions of the lungs.

Among IPAH patients, in two cases the examination that preceded NTMLD showed delicate opacities located in the whole lungs, and in one case, nodules of the central pulmonary lobule. These symptoms had been described in the examinations performed several years prior to the development of NTMLD. In the opinion of authors, these abnormalities were not an early manifestation of NTMLD because in those patients, radiological changes corresponding to infection with $M$. kansasii, similarly to other patients from this group, took the form of infiltrations with cavitation.

In IPAH patients, parenchymal lesions in the form of focal ground-glass opacities or nodules in the central part of the pulmonary lobule, which are seen on high-resolution CT (HRCT) scan, are rare. In our own research, among $48 \mathrm{IPAH}$ patients, they were found in $25 \%$ and $17 \%$ of cases, respectively [30]. The presence of nodules correlated with more advanced pulmonary hypertension and was an adverse prognostic factor [30].

The most interesting conclusions concerning CTEPH patients emerged from the analysis of correlation between the location of lesions in the course of NTMLD and the features of mosaic perfusion. Mosaic perfusion, found on HRCT scan in the patients with CTEPH, is defined as the occurrence of areas of better and worse perfusion, due to local blood flow impairment in the course of pulmonary arterial obliteration. In the study group, it was found that in all cases of CTEPH the foci of NTMLD were located in poorly perfused areas.

During the analysis of echocardiography and cardiac catheterisation, attention was paid to the fact that NTMLD concerned patients with high pulmonary pressure and significant impairment of the function of the right heart ventricle. Median TVPG was $80 \mathrm{~mm} \mathrm{Hg}$, whereas median mPAP was $49 \mathrm{~mm} \mathrm{Hg}$. The majority of patients had lowered values of cardiac index, cardiac output, and mixed venous blood oxygen saturation. An additional parameter that confirmed the presence of the impairment of the right heart ventricle function was a high value of NTproBNP.

Most patients (12 out of 13) responded positively to antituberculous treatment, which resulted in clinical and radiological improvement coupled with sterilisation of sputa. However, more than half of the patients ( 7 out of 13) died shortly after the diagnosis of non-tuberculous mycobacterial lung disease (the median time from the diagnosis of NTMLD to death was 25 months). The direct cause of death in all cases was right heart insufficiency in the course of advanced pulmonary hypertension.

It seems that infection with non-tuberculous mycobacteria could have an impact on survival in the study group. However, it was also the group with advanced pulmonary hypertension, right heart insufficiency, and poor prognosis. The median concentration of NTproBNP was $2195 \mathrm{pg} / \mathrm{ml}$ and significantly exceeded the value of $1400 \mathrm{pg} / \mathrm{ml}$, which was considered to be a negative prognostic factor in patients with PH by Fijalkowska et al. [31]. In the above-mentioned paper, $44 \%$ of patients who had a concentration of NTproBNP higher or equal to $1400 \mathrm{pg} / \mathrm{ml}$ died during three-year follow-up [31].

In the literature, there are reports concerning the negative impact of infection on the course of $\mathrm{PH}$ and prognosis of the patients. Infections are a frequent cause of exacerbations of right heart insufficiency in this group of patients, particularly in cases of advanced pulmonary hypertension [32, 33]. Infection with non-tuberculous mycobacteria causing a chronic inflammatory condition could undoubtedly have negatively influenced the course of pulmonary hypertension in the study group. 


\section{Conflict of interest}

\section{The authors declare no conflict of interest.}

\section{References:}

1. Griffith D.E., Aksamit T., Brown-Elliott B.A. et al. An official ATS/IDSA statement: diagnosis, treatment and prevention of nontuberculous mycobacterial diseases. Am. J. Resp. Crit. Care Med. 2007; 175: 367-416.

2. Field S.K., Cowie R.L. Lung disease due to the more common nontuberculous mycobacteria. Chest 2006; 129: 1653-1672.

3. Prevots D.R., Shaw P.A., Strckland D. et al. Nontuberculous mycobacterial lung disease prevalence at four integrated health care delivery systems. Am. J. Respir. Crit. Care Med. 2010; 182: 970-976.

4. Cassidy P.M., Hedberg K., Ashlen S., McNelly E., Winthrop K.L. Nontuberculous mycobacterial disease prevalence and risk factors: a changing epidemiology. Clin. Infect. Dis. 2009; 49: e124-e129.

5. O'Brien D.P., Currie B.J., Krause V.L. Nontuberculous mycobacterial disease in Northern Australia: a case series and review of the literature. Clin. Infect. Dis. 2000; 31: 958-968.

6. Sexton P., Harrison A.C. Susceptibility to nontuberculous mycobacterial lung disease. Eur. Respir. J. 2008; 31: 1322-1333.

7. Corbet E.L., Blumberg L., Gavin J.C. et al. Nontuberculous mycobacteria. Defining disease in a prospective cohort of South African miners. Am. J. Respir. Crit. Care Med. 1999; 160: 15-21.

8. Daley C.L., Heifets L. Other mycobacteria causing human disease. W: Schaaf H.S., Zumla A. (ed.). Tuberculosis. Saunders, Philadelphia 2009; 60-74.

9. Yeager H., Farah K.E. Nontuberculous mycobacterial syndromes. W: Schlossberg D. (ed.). Tuberculosis and Nontuberculosis Mycobacterial Infections. Mc Craw-Hill, New York 2006; 413-418.

10. Czajkowska M., Augustynowicz-Kopeć E., Zwolska Z. et al. Postaci płucne mykobakterioz — częstość występowania, obrazy kliniczne i czynniki predysponujące. Pneumonol. Alergol. Pol. 2002; 70: 550-560.

11. Słupek A., Zwolska Z., Miller M., Rowińska-Zakrzewska E. Mykobakterioza płuc — problem diagnostyczny i występowanie w Polsce (badanie retrospektywne). Pneumonol. Alergol. Pol. 1997; 65: 326-332.

12. Czarkowski M.P., Cielebąk E., Kondej B., Staszewska E. Choroby zakaźne i zatrucia w Polsce w 2008 roku. Narodowy Instytut Zdrowia Publicznego - Państwowy Zakład Higieny. Warszawa 2009; e: www.pzh.gov.pl/oldpage/epimeld/2008/Ch 2008.pdf

13. Iseman M.D., Buschman D.L., Ackerson L.M. Pectus excavatum and scoliosis: thoracic anomalies associated with pulmonary disease by Mycobacterium avium complex. Am. Rev. Respir. Dis. 1991; 144: 914-918.

14. Koh W.-J., Lee J.H., Kwon Y.S. et al. Prevalence of gastroesophageal reflux disease in patients with nontuberculous mycobacterial lung disease. Chest 2007; 131: 1825-1830.

15. Winthrop K.L., Yamashita S., Beekmann S.E., Polgreen P.M. Mycobacterial and other serious infections in patients receiving anti-tumor necrosis factor and other newly approved biologic therapies: case finding through the Emerging Infections Network. Clin. Infect. Dis. 2008; 46: 1738-1740.

16. Arend S.M., van Soolingen D., Ottenhoff T. Diagnosis and treatment of lung infection with nontuberculous mycobacteria. Curr. Opin. Pulm. Med. 2009; 15: 201-208.
17. De Groote M.A., Huitt G. Infections due to rapidly growing mycobacteria. Clin. Infect. Dis. 2006; 42: 1756-1763.

18. Bodle E.E., Cunningham J.A., Della-Latta P., Schluger N.W., Saiman L. Epidemiology of nontuberculous mycobacteria in patients without HIV infection, New York City. Emerg. Infect. Dis. 2008; 14 : 390-396.

19. Marras T.K., Daley C.L. Epidemiology of human pulmonary infection with nontuberculous mycobacteria. Clin. Chest Med. 2002; 23: 553-567.

20. Szturmowicz M., Fijałkowska A., Rowińska-Zakrzewska E. et al Dwa przypadki mykobakteriozy (M. kansasii) u chorych na przewlekłe nadciśnienie płucne zakrzepowo-zatorowe. Pneumonol. Alergol. Pol. 2004; 72: 523-529.

21. Olivier K.N., Weber D.J., Wallace R.J. et al. Nontuberculous mycobacteria in cystic fibrosis study group. Nontuberculous mycobacteria. I: multicenter prevalence study in cystic fibrosis. Am. J. Respir. Crit. Care Med. 2003; 167: 828-834.

22. Wickremasinghe M., Ozerovitch L.J., Davies G. et al. Nontuberculous mycobacteria in patients with bronchiectasis. Thorax 2005; 60: 1045-1051.

23. Fowler S.J., French J., Screaton N.J. et al. Nontuberculous mycobacteria in bronchiectasis: prevalence and patient characteristics. Eur. Respir. J. 2006; 28: 1204-1210.

24. Huang C.-T., Tsai Y.-J., Shu C.-C. et al. Clinical significance of isolation of nontuberculous mycobacteria in pulmonary tuberculosis patients. Respir. Med. 2009; 103: 1484-1491.

25. Wallis R.S., Broder M.S., Wong J.Y., Hanson M.E., Beenhouwer D.O. Granulomatous infectious diseases associated with tumor necrosis factor antagonists. Clin. Infect. Dis. 2004; 38: 1261-1265 (erratum: Clin. Infect. Dis. 2004; 39: 1254-1255).

26. Nightingale S.D., Byrd L.T., Southern P.M., Jockusch J.D., Cal S.X., Wynne B.A. Incidence of Mycobacterium avium-intracellulare complex bacteremia in human immunodeficiency virus-positive patients. J. Infect. Dis. 1992; 165: 1082-1085.

27. Wilińska E. Mykobakteriozy u chorych z nadciśnieniem płucnym zakrzepowo-zatorowym i idiopatycznym - analiza częstości występowania, czynników predysponujących i przebiegu leczenia. Rozprawa doktorska. Instytut Gruźlicy i Chorób Płuc. Warszawa 2012.

28. Dailloux M., Abalain M.L., Laurain C. et al. Respiratory infections associated with nontuberculous mycobacteria in non -HIV patients. Eur. Respir. J. 2006; 28: 1211-1215.

29. Słupek A. Mikobakteriozy. W: Rowińska-Zakrzewska E. (ed.). Gruźlica w praktyce lekarskiej. Wydawnictwo Lekarskie PZWL, Warszawa 2000; 271-290.

30. Kacprzak A., Szturmowicz M., Burakowska B. et al. Zmiany w tomografii komputerowej płuc o wysokiej rozdzielczości $\mathrm{u}$ chorych na idiopatyczne tętnicze nadciśnienie płucne powiązanie $\mathrm{z}$ parametrami hemodynamicznymi i znaczenie rokownicze. Pneumonol. Alergol. Pol. 2009; 77: 23-30.

31. Fijałkowska A., Kurzyna M., Torbicki A. et al. Serum $\mathrm{N}$-terminal brain natriuretic peptide as a prognostic parameter in patients with pulmonary hypertension. Chest 2006; 129: 1313-1321.

32. Kurzyna M., Żyłkowska J., Fijałkowska A. et al. Characteristics and prognosis of patients with decompensated right ventricular failure during the course of pulmonary hypertension. Kardiol. Pol. 2008; 66: 1033-1039.

33. Sztrymf B., Souza R., Bertoletti L. et al. Prognostic factors of acute heart failure in patients with pulmonary arterial hypertension. Eur. Respir. J. 2010; 35: 1286-1292. 